
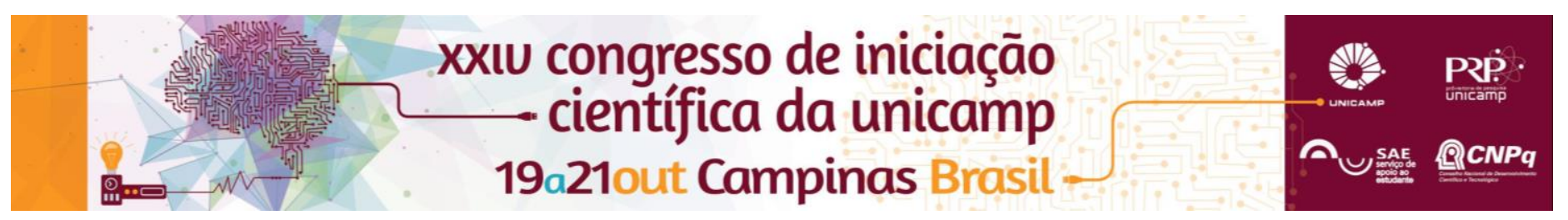

\title{
Problemas locomotores em frango de corte
}

\author{
Paola M. Taminato*, Gabriel F. Lourenço*, Flavia G. Jacob, Marta S. Baracho, Nilsa D. Lima, Irenilza A. Naas.
}

\section{Resumo}

O experimento foi conduzido no Município de Arthur Nogueira em dois aviários em galpão convencional, cortina amarela e pressão positiva. O objetivo deste estudo foi comparar e verificar maior incidência de problemas locomotores,em dois aviarios, avaliando as variávies ambientais: temperatura, umidade do ar, ventilação do ar e os índices de pododermatite e gait score. $\mathrm{O}$ aviário 1 teve como principais características cama reutilizada e aves das linhagens ROSS e COBB e o aviário 2 cama nova-pó de serra e aves apenas da linhagem ROSS. Para estimativa do gait score foram observadas 75 aves aleatoriamente em cada aviário, com idades de 25, 32 e 40 dias e para estimativa de pododermatite foram observadas 30 aves por aviário com idades de 12, 19, 29 e 40 dias. As coletas foram realizadas semanalmente. Os resultados mostraram que o aviário 1 apresentou melhores condições de conforto térmico do que o aviário 2 e o aviário 2 apresentou maiores índices de problemas locomotores.

\section{Palavras-chave: problemas locomotores, frango de corte, ambiência}

\section{Introdução}

A carne de frango é uma das produções mais lucrativas do Brasil. Em 2015, segundo a União Brasileira de Avicultura (UBABEF), além de exportar 4,3 mil toneladas desse tipo de carne e gerar uma renda de 25 bilhões de reais, o Brasil produziu mais de 13,1 milhões de toneladas de carne de frango e assumiu o lugar da China como o segundo maior produtor de carnes de frango do mundo. Com vista nesta alta produção e o seu crescimento, o cuidado com o bem-estar das aves e os parâmetros ambientais nos aviários são fatores fundamentais. Sem estes as aves entram em desconforto térmico e apresentam problemas locomotores, 0 que traz perdas econômicas e condenações em abatedouros, afetando negativamente a sua produção. Sendo assim, o estudo dessas condições torna-se relevante. $\mathrm{O}$ objetivo deste trabalho foi comparar a ambiência interna de dois aviários, um com cama reutilizada e outro com cama nova-pó de serra, e avaliar qual deles apresentou maior incidência de problemas locomotores.

\section{Resultados e Discussão}

No geral, foi observado que as variáveis ambientais não apresentaram diferenças significativas, como pode ser visualizado na Tabela 1. Porém, o aviário 1 (cama reutilizada) apresentou melhores condições de conforto térmico do que o aviário 2 (cama nova-pó de serra), com valores menores de temperatura do ar e valores maiores de umidade relativa e ventilação do ar.

Tabela 1. Variáveis ambientais

\begin{tabular}{|l|c|c|c|c|c|c|}
\hline \multicolumn{7}{|c|}{ Variáveis Ambientais } \\
\hline & \multicolumn{3}{|c|}{ Aviário 1 } & \multicolumn{3}{c|}{ Aviário 2 } \\
\hline Medidas & Temp. $\left({ }^{\circ} \mathrm{C}\right)$ & U.R. (\%) & Vent. (m/s) & Temp. $\left({ }^{\circ} \mathrm{C}\right)$ & U.R. $(\%)$ & Vent. (m/s) \\
\hline Semana 1 & 31,88 & 49,6 & 0,49 & 32,44 & 45,4 & 0,42 \\
\hline Semana 2 & 26,98 & 86,6 & 0,1 & 28,3 & 80,2 & 0,13 \\
\hline Semana 3 & 29,02 & 70,2 & 0,83 & 29,16 & 64,2 & 0,68 \\
\hline Semana 4 & 29,65 & 60,75 & 1,41 & 29,9 & 59,25 & 0,98 \\
\hline Semana 5 & 27,72 & 61,8 & 1,18 & 28,24 & 58,4 & 0,92 \\
\hline Semana 6 & 29,18 & 73,2 & 1,2 & 29,78 & 71,2 & 0,93 \\
\hline
\end{tabular}

Em relação a incidência de pododermatite, houve um número médio de aves com lesões, chegando a passar da metade das aves na semana 3 (16 aves com lesão de 30 aves) no aviário 2 , como mostra a Tabela 2 . O aviário 2 apresentou maiores índices de pododermatite em todas as semanas, exceto na semana 1 na qual não houve lesões.

Tabela 2. Número de aves com pododermatite

\begin{tabular}{|c|c|c|}
\hline \multicolumn{3}{|c|}{ Número de aves com Pododermatite } \\
\hline & Aviário 1 & Aviário 2 \\
\hline Semana 1 & 0 & 0 \\
\hline Semana 2 & 3 & 8 \\
\hline Semana 3 & 14 & 16 \\
\hline Semana 4 & 6 & 8 \\
\hline Semana 5 & 10 & 14 \\
\hline Semana 6 & 7 & 13 \\
\hline
\end{tabular}

Em relação ao gait score, houve um número baixo de aves com dificuldade de caminhar aos 25 dias de idade e um número médio aos 32 e 40 dias de idade, como mostra a Tabela 3. O aviário 2 apresentou maior índice de gait score em todas as idades. Foi observado que as aves caminham apenas para beber água, comer e mudar de local. Aos 25 dias de idade foi observado "brigas" e brincadeiras entre frangos, o que pode justificar o baixo número de aves com gait score nesta idade.

Tabela 3. Número de aves com Gait Score

\begin{tabular}{|c|c|c|}
\hline \multicolumn{3}{|c|}{ Número de aves com Gait Score } \\
\hline & Aviário 1 & Aviário 2 \\
\hline 25 dias & 19 & 21 \\
\hline 32 dias & 27 & 34 \\
\hline 40 dias & 34 & 39 \\
\hline
\end{tabular}

\section{Conclusões}

Pode-se concluir que em consequência das melhores condições de conforto térmico apresentadas no aviário 1 (cama reutilizada) do que no aviário 2 (cama nova-pó de serra), o aviário 2 apresentou maior incidência de problemas locomotores.

\section{Agradecimentos}

Ao Conselho Nacional de Desenvolvimento Científico e Tecnológico (CNPq) e a Fundação de Amparo à Pesquisa do Estado de São Paulo (FAPESP). 